\title{
Subsidiary Governance Case
}

\author{
by Martin Hilb \\ (Switzerland)
}

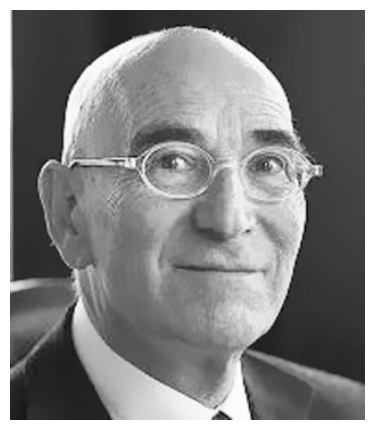

International Board Foundation and its International Center for Corporate Governance

You are the newly appointed Vice President for Europe of Computex Corporation, a San Francisco-based computer manufacturer.

This morning you received the following letter signed by six (out of ten) members of your sales force team in the recently established Swedish subsidiary, located in Gothenburg.

Each group has to analyse the situation and to develop an action plan (based on the attached form) to solve this problem in a fair and effective way.

\section{$1 \quad$ Original Letter:}

\section{Mr. Peter JONES}

Vice President-Europe Computex Corporation

San Francisco/U.S.A.

Goteborg, March 30, 2018

The writers of this letter are the headcount of the Sales Department of Computex Sweden NS, except the Sales Manager.

See Martin Hilb: "Glocal Management of Human Resources", 2nd Edition, LIT Zurich \& Berlin 2009, pp. 181-184 
We have decided to bring to your attention a problem which unsolved probably will lead to a situation where the majority among us will leave the company within a rather short period of time. None of us want to be in this situation, and we are approaching you purely as an attempt to save the team to the benefit of ourselves as well as Computex Corporation.

We consider ourselves an experienced, professional and sales-oriented group of people. Computex Corporation is a company which we are proud to work for. The majority among us have been employed for several years. Consequently a great number of key customers in different areas of Sweden see us as representatives of Computex Corporation. It is correct to say that the many excellent contacts we have made have been established over years; many of them are friends of ours. Short background because we have never met you. What kind of problem forces us to such a serious step as to contact you? Problems arise as a result of character traits and behaviour of our General Manager, Mr. Miller. We are more convinced that we are tools that he is utilizing in order to "climb the ladder". In meetings with us individually, or as a group, he gives visions about future, how he values us, how he wants to delegate and involve us in business, the importance of cooperation, communication, etc. When it comes to the point, these phrases turn out to be only words.

Mr. Miller loses his temper almost daily, and his outbursts and reactions are not equivalent to the possible error. His mood and views can change almost from hour to hour. This fact causes a situation where we feel uncertain when facing him and consequently are reluctant to do so. Regarding human relationship his behaviour is not acceptable, especially for a manager.

The extent of the experience of this varies within the group due to our location. Some of us are seldom in the office.

Secondly we have experienced clearly that he has various means of suppressing and discouraging people within the organization.

The new "victim" is our Sales Manager, Mr. Johansson. Because he is our boss, it is obvious that we regret such a situation, which to considerable extent influences our working conditions.

There are also other "victims" among us. It is indeed very difficult to carry through what is stated in our job descriptions.

We feel terribly sorry and wonder how it can be possible for one person to ruin a whole organization.

If this group had consisted of people less mature, many of us would have left Computex already. So far only one has left the company due to the above reasons.

From September 1, two new Sales Representatives will be joining the company. We regret very much that new employees get their first contact with the company under the present circumstances. An immediate action is therefore required. 
It is not our objective to get rid of Mr. Miller as General Manager.

Without going into details, we are thankful for what he has done for the company from a business point of view. If he could control his mood, show some respect for his colleagues, keep words and stick to plans, we believe that we can succeed under his leadership.

We are fully aware of the seriousness of contacting you, and we have been in doubt whether or not to contact you directly before talking to Mr. Miller.

After serious discussions and considerations, we have reached the conclusion that a problem of this nature unfortunately cannot be solved without some sort of action from the superior. If possible, direct confrontation must be avoided. It can only make things worse.

We are hoping for a positive solution.

Six of your Sales Representatives in Sweden

\section{ITTACHMENT 2:}

TRRICTLY PERSONAL/CONFIDENTIAL

\section{ACTION PLAN}

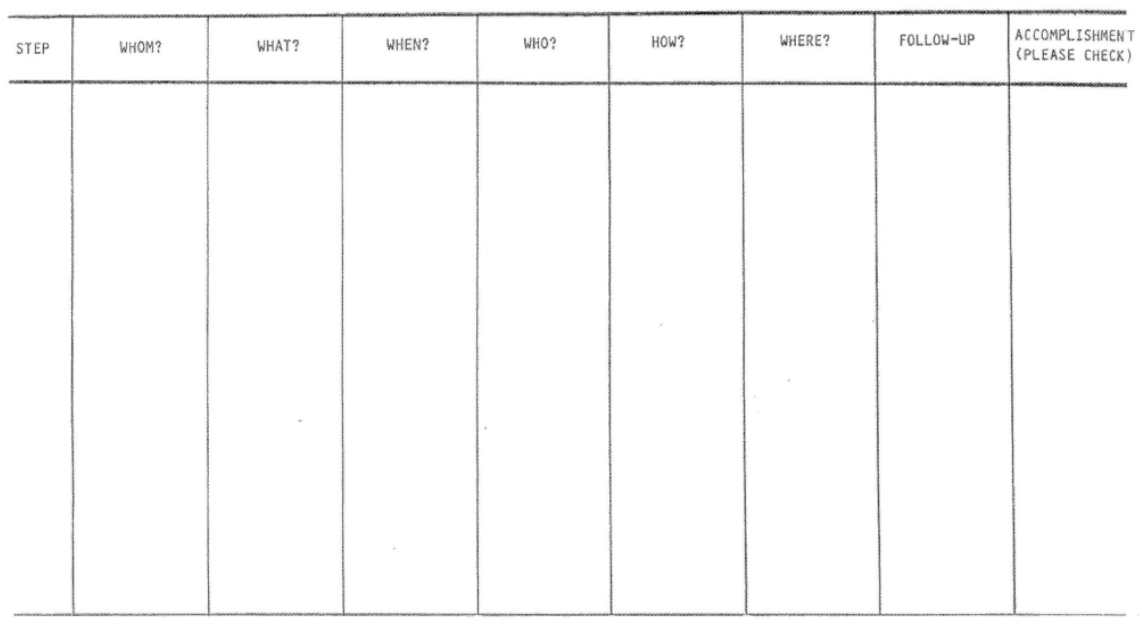

CASE GUIDE

Case guide 
STRICTLY PERSONAL/CONFIDENTIAL.

ACTION PLAN

\begin{tabular}{|c|c|c|c|c|c|c|c|}
\hline KTION STEP & Чно? & "Инат? & WHEN? & WHOM? & How? & HHERE? & FOLLOU-UP \\
\hline $\begin{array}{l}\text { 1) Inform Miller of the } \\
\text { letter and his inten- } \\
\text { tion to fly in tomorror } \\
\text { to see him and the } \\
\text { letter signaturies. }\end{array}$ & Jones & calls & now & Miller & by phone & at home & $\checkmark$ \\
\hline $\begin{array}{l}\text { 2) Arrange group } \\
\text { meeting with letter } \\
\text { signaturies. }\end{array}$ & Jones & calls & af terwards & \begin{tabular}{|l|} 
letter \\
signaturies
\end{tabular} & by phone & at home & $\checkmark$ \\
\hline $\begin{array}{l}\text { 3) Discuss perceived } \\
\text { problems. }\end{array}$ & Jones & meets & $\begin{array}{l}\text { tonorrow } \\
3 \text { pai } \\
\text { (arrival } \\
\text { tine) }\end{array}$ & Miller & $\begin{array}{l}\text { conference } \\
\text { room meeting }\end{array}$ & $\begin{array}{l}\text { Stockholm } \\
\text { airport }\end{array}$ & $v$ \\
\hline $\begin{array}{l}\text { 4) Discuss written } \\
\text { issues. }\end{array}$ & Jones & meets & $\begin{array}{l}\text { tomorrow } \\
6 \mathrm{pen}\end{array}$ & $\begin{array}{l}\text { letter } \\
\text { signaturies }\end{array}$ & group & $\begin{array}{l}\text { Hotel } \\
\text { Conference } \\
\text { room in } \\
\text { Stockholm }\end{array}$ & $v$ \\
\hline $\begin{array}{l}\text { 5) Discuss written } \\
\text { issues with Sales } \mathrm{Hgr} \text {. }\end{array}$ & Jones & meets & $\begin{array}{l}\text { the follow- } \\
\text { ing day } \\
8 \text { ana }\end{array}$ & Johansson & \begin{tabular}{|} 
conference \\
roora meeting
\end{tabular} & same hotel & $\checkmark$ \\
\hline $\begin{array}{l}\text { 6) Meet other Sales } \\
\text { Representatives (who } \\
\text { did not sign the letter }\end{array}$ & Jones & meets & $\begin{array}{l}9 \text { am } \\
\left(20^{\prime} \text { per }\right. \\
\text { individual })\end{array}$ & $\begin{array}{l}4 \text { other } \\
\text { Sales Repre- } \\
\text { sentatives }\end{array}$ & $\begin{array}{l}\text { individual } \\
\text { meetings }\end{array}$ & same hotel & $\checkmark$ \\
\hline $\begin{array}{l}\text { 7) Meet other depart- } \\
\text { ment heads (reporting } \\
\text { to the General Manager) }\end{array}$ & Jone:s & neets & $\begin{array}{l}10.30 \text { an } \\
\left(30^{\circ} \text { per }\right. \\
\text { individua } 1)\end{array}$ & $\begin{array}{l}3 \text { other } \\
\text { department } \\
\text { hoads }\end{array}$ & $\begin{array}{l}\text { individual } \\
\text { tteetings }\end{array}$ & same hotel & $\checkmark$ \\
\hline $\begin{array}{l}\text { 8) Inform Gn about } \\
\text { Steps 4) to 7) }\end{array}$ & Jones & meets & 12 an & Miller & lunch & same fotel. & $v$ \\
\hline
\end{tabular}

Action plan

\section{$2 \quad$ What Happened in Reality?}

The same night Jones prepared his trip by studying parts of two books he had read long time ago:

- The chapter about "Sweden" in the book Multicultural Management

- The chapter about "Group Psychology" in the book Conflict Management

After having read the simplicities, Peter was aware of the facts that the Swedish environment differs very much from the American one and that it is essential to know as much as possible about the characteristics of team building in Scandinavian countries.

When Jones met Miller at the airport and after reviewing the letter, Miller pointed out that in his opinion the letter was initiated by the Sales Manager.

During the group meeting with the six Sales Representatives, the General Manager was again accused of his perceived inappropriate behaviour. Jones repeatedly asked them to verify their statements. But no individual was able to do so. The result of the long group meeting (which ended after midnight) was that the Sales Manager had initiated them to originate the letter. 
The next step was obvious: Jones met the Sales Manager and confronted him with the findings of his group meeting with the Sales Representatives. The Sales Manager reacted by admitting it was true. As a consequence of his action, the Sales Manager agreed to leave the company with immediate effect.

The other department heads, the Sales Force and the other staff were informed about this agreement accordingly: effective immediately, all Sales Representatives were appointed Sales Managers of their district reporting directly to the General Manager. By this decision, one management level was eliminated; the jobs of the Sales Representatives were enriched, evaluated and compensated higher and information falsification, bureaucracy and overall costs reduced.

This case demonstrated two things. If, there is a leadership problem:

1. First we always have to determine where the cause of the problem is located, on the individual or group or organizational level.

In our Case if Jones would not have asked this question, the risk to the organization would have been the loss of an effective executive.

2. Second we always have to be aware of the whole situation by using a $360^{\circ}$ view of the perceived problem.

Open Access This chapter is licensed under the terms of the Creative Commons Attribution 4.0 International License (http://creativecommons.org/licenses/by/4.0/), which permits use, sharing, adaptation, distribution and reproduction in any medium or format, as long as you give appropriate credit to the original author(s) and the source, provide a link to the Creative Commons licence and indicate if changes were made.

The images or other third party material in this chapter are included in the chapter's Creative Commons licence, unless indicated otherwise in a credit line to the material. If material is not included in the chapter's Creative Commons licence and your intended use is not permitted by statutory regulation or exceeds the permitted use, you will need to obtain permission directly from the copyright holder.

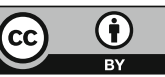

